\title{
THOC5 wt Allele
}

National Cancer Institute

\section{Source}

National Cancer Institute. THOC5 wt Allele. NCI Thesaurus. Code C54396.

Human THOC5 wild-type allele is located in the vicinity of $22 q 12.2$ and is approximately $48 \mathrm{~kb}$ in length. This allele, which encodes THO complex subunit 5 homolog protein, may be involved in the regulation of messenger RNA transport. 